\title{
Effect of anthropogenic disturbances on biomass and carbon storage potential of a dry tropical forest in India
}

\author{
G. V. Pawar, Lalji Singh, M. K. Jhariya* and K. P. Sahu \\ Department of Forestry College of Agriculture, Indira Gandhi Krishi Vishwavidyalaya, Raipur- 492012 (C.G.), \\ INDIA \\ *Corresponding author. E-mail: manu9589@gmail.com
}

Received: April 19, 2014 Revised received: August 16, 2014 .; Accepted: September 25, 2014

\begin{abstract}
The forests of Chhattisgarh ares very well known for its species richness, diversity, biomass, carbon stock and productivity. The present study was carried out at Katghora forest division under Bilaspur circle of Korba district, Chhattisgarh considering three sites viz., least, moderately and highly disturbed site to estimate biomass and carbon storage in relation to anthropogenic disturbances. For collection of data quadrats were selected under stratified random sampling design. For enumeration of tree and saplings ten quadrats of $10 \mathrm{~m} \times 10 \mathrm{~m}$ were laid and each species counted separately. The tree density varies from $100-510$ stems ha ${ }^{-1}$ across study sites. Total biomass in the present study was between $127.69 \mathrm{t} \mathrm{ha}^{-1}$ and $227.71 \mathrm{t} \mathrm{ha}^{-1}$. Total above ground biomass was between $111.20 \mathrm{t}$ $\mathrm{ha}^{-1}$ and $199.42 \mathrm{t} \mathrm{ha}^{-1}$, whereas total below ground biomass varied from 16.49-28.29 $\mathrm{t} \mathrm{ha}^{-1}$, respectively. The total carbon storage across the sites were ranged from 55.125 to $98.548 \mathrm{t} \mathrm{C} \mathrm{ha}^{-1}$ found higher under least disturbed site and lowest under medium disturbed site. Carbon storage pattern according to girth class followed the similar trend of distribution as was in the case of biomass. It has least proportion in small girth class and maximum storage under the higher girth class. It is evident from the study that disturbances have significant impact on density, vegetation diversity, biomass accumulation and carbon storage pattern. Conservation affords are required to control on disturbances and for the natural recovery of forest ecosystem.
\end{abstract}

Keywords: Biomass, Carbon storage, Diversity, Species richness, Tropical forests

\section{INTRODUCTION}

The tropical forests have well known for its vegetation diversity, species richness as well as important role in biomass accumulation and in carbon cycle. Anthropogenic disturbance can change the successional pattern of stand, subsequent diversity and biomass of forest. Quantification of biomass is required to better know the structure and functions of the ecosystem (Ovington, 1962; Brown et al., 1999) and for evaluate the status and trends of forest ecosystems along the wide range of environmental gradients. The structural and functional processes have to be quantified for thoroughly understanding the vegetation dynamics. On the other hand, woody biomass is also necessary for determining the status and flux of biological materials in an ecosystem (Anderson, 1970). Understanding the patterns of storage and production of organic matter in forests in relation to the disturbances is critical for management purposes and an essential aspect of studies of carbon cycle (Keller et al., 2001; Ketterings et al., 2001; Cairns et al., 2003) which can also be used to understand changes in forest structure resulting from succession or to differentiate between forest types (Cairns et al., 2003). In the last few years, there has been increasing interest in the quantification of the biomass of forest ecosystems and its potential C fixation (Usuga et al., 2010; Jhariya, 2014; Jhariya et al., 2014). Live tree biomass pool is an important source of uncertainty in $\mathrm{C}$ balance from the tropical regions in part due to scarcity of reliable estimates of tree biomass and its variation across landscapes and forest types (Alves et al., 2010).

In developing countries, protected forests are facing high anthropogenic disturbance due to fire, grazing, lopping, felling, fuel wood extraction and collection of non - timber forest products (NTFPs) for livelihood of forest dwelling populations (Jhariya et al., 2014). The total forest cover of India is $21.05 \%$ of the geographical area and have the total carbon stock in India's forests is to be $6663 \mathrm{~m}$ tones (FSI, 2011). In Chhattisgarh biotic interference are more frequent in tropical deciduous forests and limited work has been done in these forests in relation to different anthropogenic disturbance gradient (Singh et al., 2009; Jhariya, 2010; Pawar et al., 2012; Jhariya et al., 2012; Jhariya et al., 2014; Kittur et al., 2014). These factors causing great loss to biodiversity and ultimately destructing the natural vegetation and habitat of the region. However, there is severe ongoing anthropogenic pressure on the tropical forests which calls for sustainable forestry to 
reduce poverty, integrating forests into sustainable economic development and protecting local and global forest values. Understanding vegetation changes following the disturbances caused by different factors is essential for developing management practices involving natural regeneration and to maintain the overall biodiversity, productivity and sustainability. Presently there is a dearth of information on the effect of anthropogenic disturbances on biomass, carbon storage potential of such forest. So, present study was carried out to fill the knowledge gap regarding this attributes.

\section{MATERIALS AND METHODS}

The study was carried out at Katghora forest division under Bilaspur circle of Korba district (Chhattisgarh) during the year 2010-2011. The area was located between $22^{\circ} 26^{\prime} 49^{\prime \prime}$ to $22^{\circ} 28^{\prime} 74^{\prime \prime}$ North latitudes and $82^{\circ} 19^{\prime} 30^{\prime \prime}$ to $82^{\circ} 22^{\prime} 97^{\prime \prime}$ East longitudes. It comprises about 4187.371 sq. $\mathrm{km}$ of which 2834.968 sq. $\mathrm{km}$ was protected forests area and 1352.403 sq. $\mathrm{km}$ was unclassified forests. Physiographically the area comes under Satpura and Maikal Mountain ranges and generally the topography was undulated. The climate of study area was sub humid to humid and the average annual rainfall of area ranges from 1000-1250 mm. Three types of soils are found in study area i.e. red soil, literate soil and mountain soil. Different types of forest vegetation occur in the study area.

For collection of data quadrats were selected under stratified random sampling design considering three sites viz., least, moderately and highly disturbed site as strata. In order to understand the effect of different sites on various variables viz., density, biomass and carbon storage. At each site, the vegetation was sampled in ten randomly placed quadrats. For enumeration of tree and saplings a quadrats sized $10 \mathrm{~m}$ $\times 10 \mathrm{~m}$ were laid, while for seedling $2 \mathrm{~m} \times 2 \mathrm{~m}$ quadrats were laid and each species counted separately for quantify their density, biomass and carbon storage. For the measurement of tree biomass, allometric equation relating tree circumference to biomass developed earlier by Singh and Mishra (1979) and Singh and Singh (1991) for the dry deciduous forest species were used. The tree individuals in each quadrate were categorized into different girth classes. The mean circumference at breast height value for each species for a girth class was used in the regression equation to get an estimate of biomass (by component i.e. bole, branch, foliage and root) for that girth class. Then this value was multiplied by the density of trees in that girth class. The girth class values were summed to obtain the biomass estimate for each of the quadrates in each site. The Carbon concentration was analyzed using CHNOS-Auto Analyzer "Elementar Vario EL". Carbon storage in the vegetation was calculated by multiplying biomass and carbon concentration of different component separately for respective species (Sahu et al., 2013).

\section{RESULTS AND DISCUSSION}

Effect on density and biomass in different sites: Across the study sites (Table 1) in tree layer 10 species was found on least disturbed site, 12 species on moderately disturbed site and 6 species on highly disturbed site, whereas in the case of sapling layer it was 9 species in both least disturbed and moderately disturbed site and 2 species on highly disturbed site, respectively. A total of 14 species of seedlings were recorded on least disturbed site, 8 species on moderately disturbed site and 4 species on highly disturbed site. The tree density on least disturbed, moderately disturbed and highly disturbed sites varied greatly and it was highest on least disturbed site (510 stems $\left.\mathrm{ha}^{-1}\right)$ followed by moderately disturbed site ( 310 stems $\left.\mathrm{ha}^{-1}\right)$ and lowest on highly disturbed site (100 stems $\left.\mathrm{ha}^{-1}\right)$. The sapling density was highest on moderately disturbed site $\left(610\right.$ stems $^{-1}$ ) followed by least disturbed site (490 stems $\mathrm{ha}^{-1}$ ) and lowest on highly disturbed site (30 stems ha ${ }^{-1}$ ) while seedling density was highest on least disturbed site (39500 stems $\mathrm{ha}^{-1}$ ) followed by moderately disturbed site (26000 stems $\mathrm{ha}^{-1}$ ) and lowest on highly disturbed site $\left(7750\right.$ stems $^{-1} \mathrm{ha}^{-1}$. The total basal area of tree layer across the site varied from $11.47-26.67 \mathrm{~m}^{2} \mathrm{ha}^{-1}$, highest under least disturbed site and lowest in moderately disturbed site.

Total biomass (Table 2) in the present study was between $127.69 \mathrm{t} \mathrm{ha}^{-1}$ and $227.71 \mathrm{t} \mathrm{ha}^{-1}$. It was highest on least disturbed site (227.71 $\mathrm{t} \mathrm{ha}^{-1}$ ) followed by highly disturbed site $\left(183.20 \mathrm{t} \mathrm{ha}^{-1}\right)$ and lowest on moderately disturbed site $\left(127.69 \mathrm{t} \mathrm{ha}^{-1}\right)$. Total above ground biomass was between $111.20 \mathrm{t} \mathrm{ha}^{-1}$ and $199.42 \mathrm{t}$ $\mathrm{ha}^{-1}$, whereas total below ground biomass was between $16.49 \mathrm{t} \mathrm{ha}^{-1}$ and $28.29 \mathrm{t} \mathrm{ha}^{-1}$, respectively. The total biomass for least disturbed site (Table 2) was $227.71 \mathrm{t}$ $\mathrm{ha}^{-1}$ of which $199.42 \mathrm{t} \mathrm{ha}^{-1}$ was above ground and 28.29 $\mathrm{t} \mathrm{ha}^{-1}$ was below ground biomass. The distribution of biomass in the different components was $117.25 \mathrm{t} \mathrm{ha}^{-1}$ in bole, $74.84 \mathrm{t} \mathrm{ha}^{-1}$ in branch, $7.32 \mathrm{t} \mathrm{ha}^{-1}$ in leaf and $28.29 \mathrm{t} \mathrm{ha}^{-1}$ in coarse root. The bole, branch, leaf and root constitute about $51.49,32.86,3.21$ and $12.42 \%$, respectively of the total biomass. Among the individual species Shorea robusta constitutes the highest biomass (110.31 tha ${ }^{-1}$ ) followed by Madhuca latifolia (43.70 $\mathrm{t} \mathrm{ha}^{-1}$ ) and Syzygium cumini (30.82 $\left.\mathrm{t} \mathrm{ha}^{-1}\right)$, which contributed $48.44,19.19$ and $13.53 \%$ of the total biomass. The total above ground biomass for moderately disturbed site was $111.20 \mathrm{t} \mathrm{ha}^{-1}$ and $16.49 \mathrm{t} \mathrm{ha}^{-1}$ was below ground biomass constituting about $127.69 \mathrm{t} \mathrm{ha}^{-1}$ of total biomass of site (Table 2). The distribution of biomass by components was $53.21 \%$ in bole, $30.13 \%$ in branch, $3.57 \%$ in leaf and $12.91 \%$ in coarse root. The bole, branch, leaf and root constitute about $67.95 \mathrm{t}$ $\mathrm{ha}^{-1}, 38.48 \mathrm{t} \mathrm{ha}^{-1}, 4.56 \mathrm{t} \mathrm{ha}^{-1}$ and $16.49 \mathrm{t} \mathrm{ha}^{-1}$ biomass, respectively of the total biomass. Among the individual species Terminalia alata constituted the highest biomass (48.71 $\mathrm{t} \mathrm{ha}^{-1}$ ) followed by Lannea 


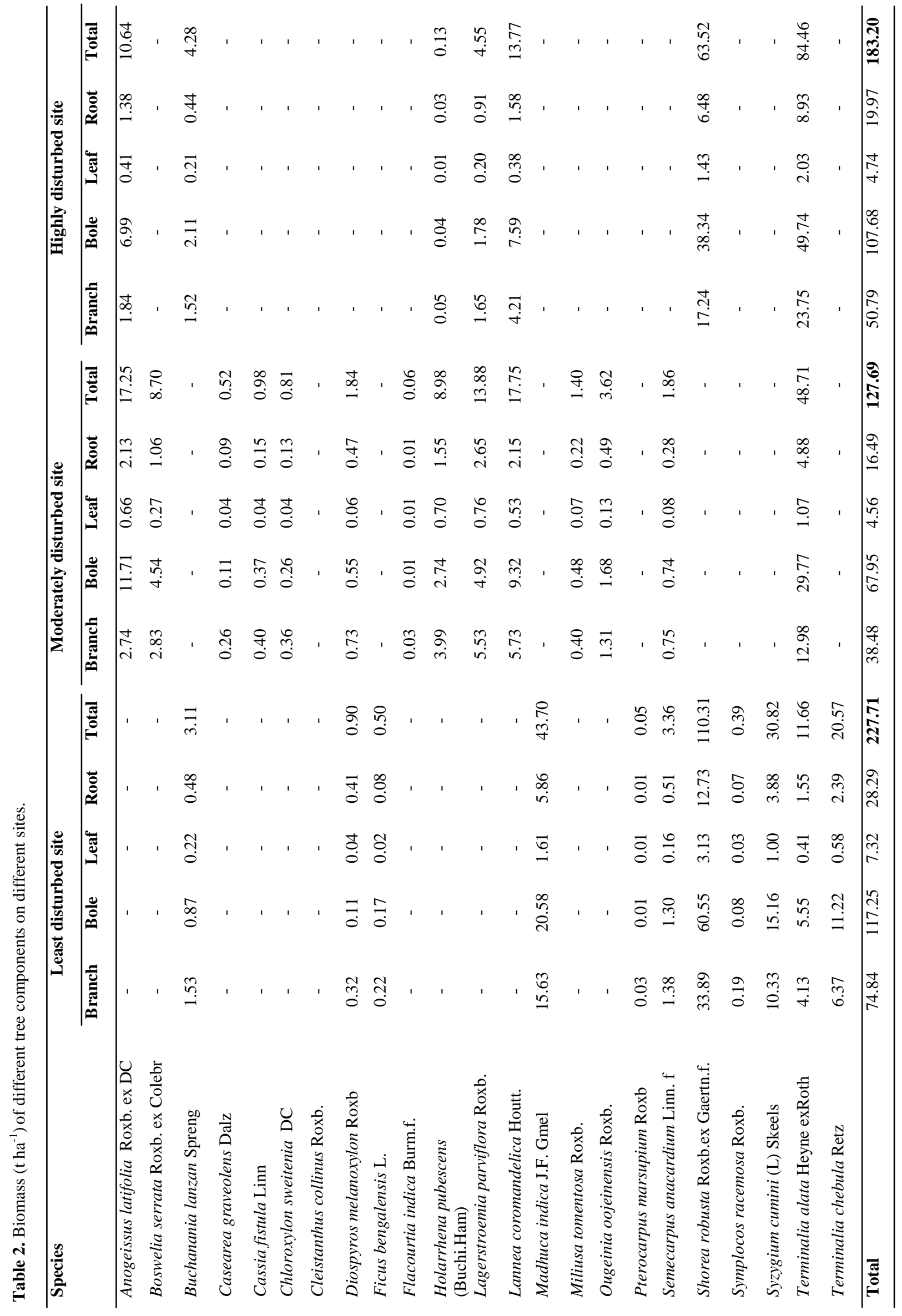


Table 3. Effect of altitude and lopping intensity on plant density, basal area and biomass.

\begin{tabular}{|c|c|c|c|c|c|c|}
\hline \multirow[b]{2}{*}{$\mathbf{Y}$} & \multicolumn{3}{|c|}{ Altitude (m) } & \multicolumn{3}{|c|}{ Lopping intensity (\%) } \\
\hline & $\mathbf{a}$ & b & $\mathbf{r}$ & $\mathbf{a}$ & b & $\mathbf{r}$ \\
\hline Seedling density (plants/ha) & $-6109^{* * *}$ & $14.55^{* *}$ & $0.7641^{* *}$ & $4288^{* *}$ & $-36.08^{* *}$ & $-0.6921^{\text {*** }}$ \\
\hline Sapling density (plants/ha) & $-105.0^{* *}$ & $0.242^{* *}$ & $0.6396^{* *}$ & $64.150^{* *}$ & $-0.517^{* *}$ & $-0.4979^{* *}$ \\
\hline Tree density (stems/ha) & $-81.88^{* *}$ & $0.1915^{* *}$ & $0.7197^{* *}$ & $59.359^{* *}$ & $-0.560^{* *}$ & $-0.7696^{* *}$ \\
\hline Basal area $\left(\mathrm{m}^{2} / \mathrm{ha}\right)$ & $-1.068^{\mathrm{NS}}$ & $0.0048^{* *}$ & $0.3780^{*}$ & $2.439^{* *}$ & $-0.013^{*}$ & $-0.3839^{*}$ \\
\hline Biomass (t/ha) & $9.859^{\mathrm{NS}}$ & $0.013^{\mathrm{NS}}$ & $0.114^{\mathrm{NS}}$ & $19.543^{* *}$ & $-0.031^{* *}$ & $-0.0919^{\mathrm{NS}}$ \\
\hline
\end{tabular}

Note: *Significant at $\mathrm{p} \leq 0.05$, **Significant at $\mathrm{p} \leq 0.01$, NS Non significant, $\mathrm{x}=$ Independent variable, $\mathrm{y}=$ Dependent variable, $a=$ intercept,$b=$ Regression coefficient, $r=$ Correlation coefficient

coromandelica (17.75 $\left.\mathrm{t} \mathrm{ha}^{-1}\right)$ and Anogeissus latifolia $\left(17.25 \mathrm{t} \mathrm{ha}^{-1}\right)$ which constitute about $38.14,13.90$ and $13.50 \%$ of the total biomass.

The total biomass for highly disturbed site was 183.20 $\mathrm{t} \mathrm{ha}^{-1}$ of which $163.23 \mathrm{t} \mathrm{ha}^{-1}$ was above ground and $19.97 \mathrm{t} \mathrm{ha}^{-1}$ was below ground biomass (Table 2 ). The distribution of biomass in the different components was $107.68 \mathrm{t} \mathrm{ha}^{-1}$ in bole, $50.79 \mathrm{t} \mathrm{ha}^{-1}$ in branch, $4.74 \mathrm{t}$ $\mathrm{ha}^{-1}$ in leaf and $19.97 \mathrm{t} \mathrm{ha}^{-1}$ in coarse root. The bole, branch, leaf and root biomass constitute about 58.77, $27.72,2.58$ and $10.90 \%$, respectively of the total biomass. Among the individual species Terminalia $T$. alata constituted the highest biomass (84.46 $\mathrm{t} \mathrm{ha}^{-1}$ ) followed by $S$. robusta $\left(63.52 \mathrm{t} \mathrm{ha}^{-1}\right)$ and $L$. coromandelica (13.77 $\left.\mathrm{t} \mathrm{ha}^{-1}\right)$ which constitute about $46.10,34.67$ and $7.51 \%$ of the total biomass.

The Bartlett's test in case of biomass was significant at $5 \%$ level this violates the basic assumption of homogeneity of variances of sites for analysis of variance. When the reason was traced it was observed that the highly disturbed site coincidently contained nearly equal quantity of biomass, due to which the variability within site (highly disturbed site) was almost negligible, which forced the heterogeneity of variances among all the sites, which includes highly disturbed site too. It may be noted here that the site variances should be homogeneous before going for analysis of variance of the sites. This is tested by the Bartlett's test. Thus, this problem is not that of the sites, rather it is a coincidental problem in which all the quadrats have similar values. On a larger canvass the quadrat's constituent may not be the same. Therefore, although technically we cannot proceed, having given this caution, we are still proceeding to have an idea about the significance of difference due to sites on the biomass, whose F-test turns out to be non-significant at the $5 \%$ level of significance.

Although the young individuals belonging to seedlings and saplings classes dominated all the three site in terms of density but the total biomass accumulation was greater in the $>100 \mathrm{~cm}$ girth class (Fig. 1). In least disturbed site the total biomass accumulation was greater in the $>100 \mathrm{~cm}$ girth class followed by middle girth class while it was minimum in smaller girth classes (Fig. 2). About 52.33\% biomass accumulation was in the girth class $>100 \mathrm{~cm}, 37.22 \%$ in girth class $60-100 \mathrm{~cm}, 8.24 \%$ in girth class $30-60 \mathrm{~cm}$ and $2.18 \%$ in smaller girth class $10-30 \mathrm{~cm}$. In moderately disturbed site the total biomass accumulation was greater in the $>100 \mathrm{~cm}$ girth class followed by middle girth class while it was minimum in smaller girth classes (Fig. 3). About $64.95 \%$ biomass accumulation was in the girth class $>100 \mathrm{~cm}, 18.24 \%$ in girth class $60-100 \mathrm{~cm}$, $11.62 \%$ in girth class $30-60 \mathrm{~cm}$ and $5.17 \%$ in smaller girth class $10-30 \mathrm{~cm}$. In highly disturbed site the total biomass accumulation was greater in the $>100 \mathrm{~cm}$ girth class while it was minimum in middle girth classes (Fig. 4). About $89.17 \%$ biomass accumulation was in the girth class $>100 \mathrm{~cm}, 10.62 \%$ in girth class $60-100 \mathrm{~cm}$ and $0.19 \%$ in smaller girth class $10-30 \mathrm{~cm}$. Total biomass accumulation in the $>100 \mathrm{~cm}$ girth class was greater at highly disturbed site followed by least disturbed and moderately disturbed site. While in 60 $100 \mathrm{~cm}$ girth class was greater at least disturbed site followed by moderately disturbed and minimum at highly disturbed site. In 30-60 cm girth class greater at moderately disturbed site followed by least disturbed site and in 10-30 cm girth class greater at moderately disturbed site followed by least disturbed and highly disturbed site.

The correlation analysis indicates that there was a positive influence of altitude whereas, negative influence of lopping intensity on density, basal area and biomass. There was a strong positive influence of altitude on seedling density $(r=7641)$, sapling density $(r=6396)$ and tree density $(r=0.7195)$ while there was negative influence of lopping intensity on seedling density ( $\mathrm{r}=$ $0.6921)$, sapling density $(r=-0.4979)$ and tree density $(\mathrm{r}=-0.7696)$ at $1 \%$ levels of significance. The correlation analysis for basal area indicates that there was a positive correlation $(r=3780)$ between basal area and altitude while, there was negative correlation ( $\mathrm{r}=$ -0.3839 ) between basal area and lopping intensity at $5 \%$ levels of significance. It was found that biomass was not significantly correlated with $(r=0.114)$ altitude and $(r=-0.0919)$ lopping intensity. Regression line indicates that with $1 \mathrm{~m}$ increase in altitude the density, basal area and biomass get increased while with $1 \%$ increase in lopping intensity the density, basal area and biomass get decreased (Table 3 ). 
G. V. Pawar et al. / J. Appl. \& Nat. Sci. 6 (2): 383-392 (2014)

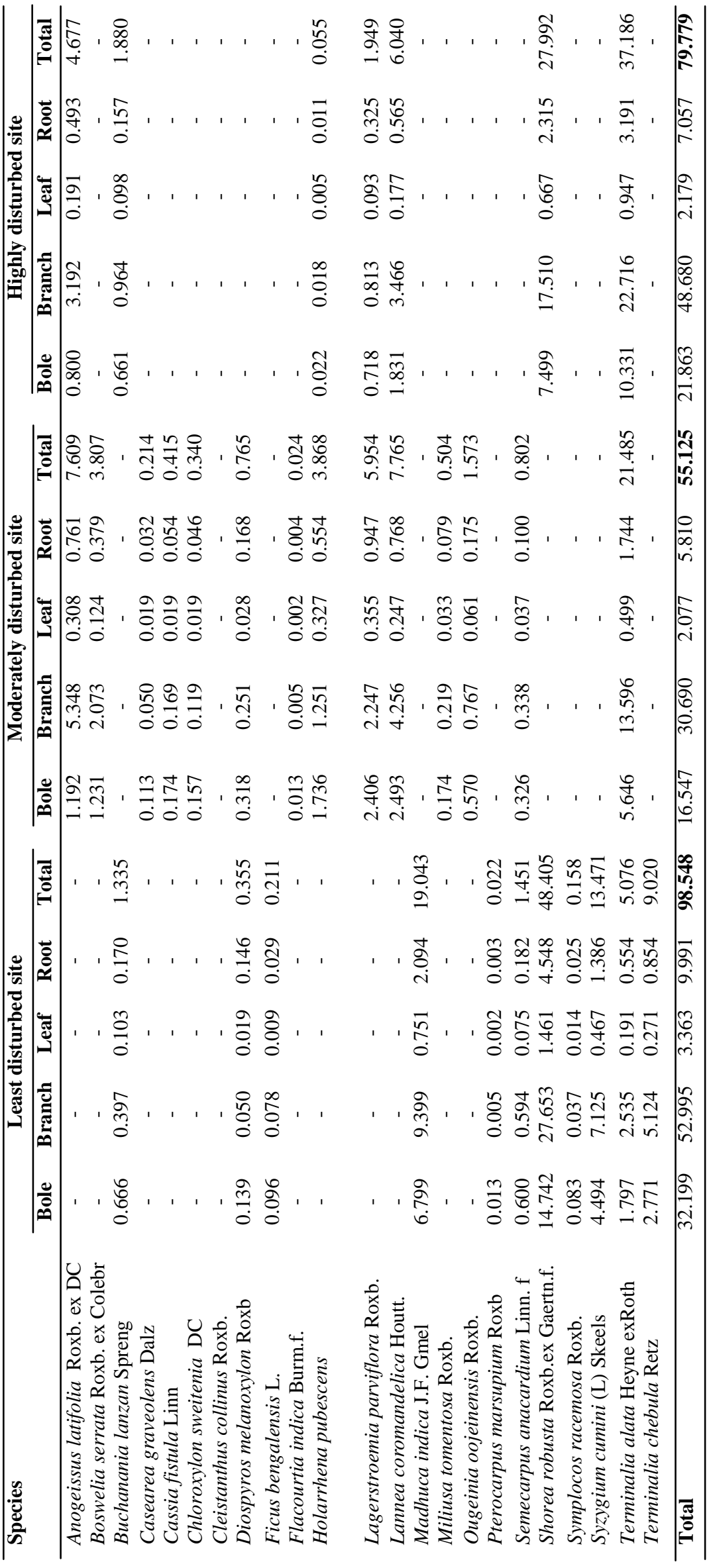


The total carbon storage across the sites were ranged from 55.125 to $98.548 \mathrm{t} \mathrm{C} \mathrm{ha}^{-1}$ found higher under least disturbed site and lowest under medium disturbed site (Table 4). In least disturbed site the distribution of carbon was $32.199 \mathrm{t} \mathrm{C} \mathrm{ha}^{-1}$ in bole, $52.995 \mathrm{t} \mathrm{C} \mathrm{ha}^{-1}$ in branch, $3.363 \mathrm{t} \mathrm{C} \mathrm{ha}^{-1}$ in leaf and $9.991 \mathrm{t} \mathrm{C} \mathrm{ha}^{-1}$ in coarse root, respectively. Out of the total carbon storage the bole constituted $32.67 \%$, branch $53.78 \%$, leaf $3.41 \%$ and $10.14 \%$ by coarse roots, respectively. Among the recorded species under least disturbed site the higher carbon stored by $S$. robusta followed by $M$. indica and S. cumini, which contributed about $82.11 \%$ in total, whereas the lowest value were recorded by Pterocarpus marsupium, Symplocos racemosa, Ficus bengalensis and Diospyros melanoxylon. The moderately disturbed site had the total carbon storage value of $55.125 \mathrm{t} \mathrm{C} \mathrm{ha}^{-1}$ out of which $49.315 \mathrm{t} \mathrm{C} \mathrm{ha}^{-1}$ stored in above ground components and remaining (5.810 $\mathrm{C}$ ha ${ }^{1}$ ) in coarse roots, respectively. Among the individual species $T$. alata constituted the highest carbon storage (38.98\%) in total C storage. Among different components under the moderately disturbed site followed the order:

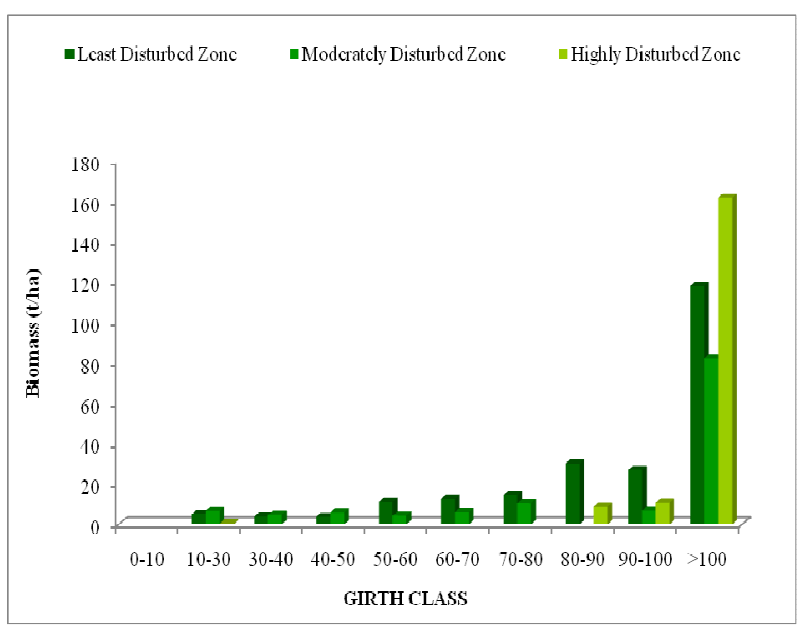

(Fig. 1)

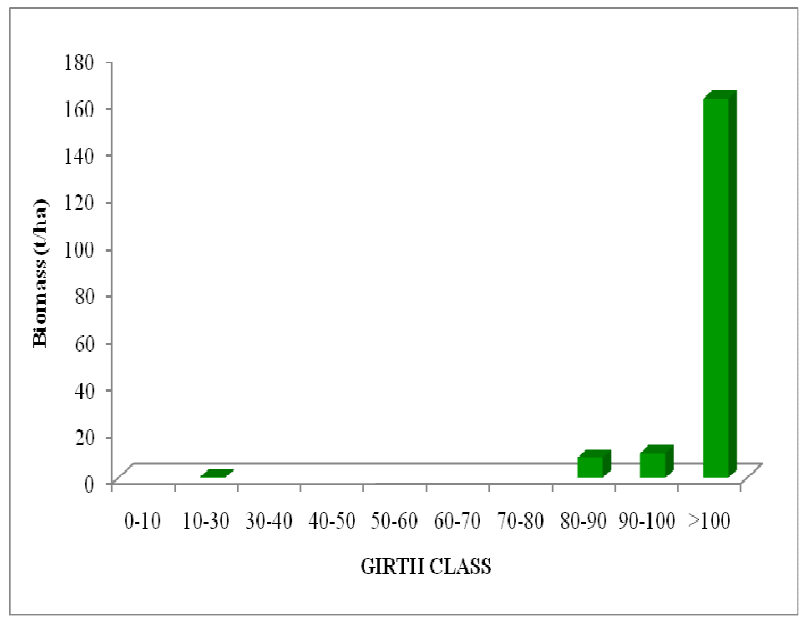

(Fig. 3) branch $(55.67 \%)>$ bole $(30.02 \%)>\operatorname{root}(10.54 \%)>$ leaf $(3.77 \%)$ of the total $\mathrm{C}$ storage. Under the highly disturbed site a total of $79.779 \mathrm{t} \mathrm{C} \mathrm{ha}^{-1}$ were quantified in which $27.40 \%$ shared by bole, $61.02 \%$ by branch, $2.73 \%$ by leaf and $8.85 \%$ by coarse root, respectively. Among the all species highest value of carbon storage was recorded under T. alata $(37.186 \mathrm{t} \mathrm{C}$ $\mathrm{ha}^{-1}$ ) and $S$. robusta $\left(27.992 \mathrm{t} \mathrm{C} \mathrm{ha}^{-1}\right)$, while the minimum were found by Holarrhena pubescens $(0.055$ t $\mathrm{C} \mathrm{ha}{ }^{-1}$ ), respectively. Distribution pattern of carbon storage as per the girth class also followed the similar trend as was in the case of biomass distribution. It was found negligible in lowest girth class specially belonging saplings and peak storage was observed in higher girth class.

The biomass of the stand or forest depends on species their density, size class, age and site condition of the region. The biomass stock significantly changed by disturbances, land use, harvesting and climatic variability (Canadell et al., 2007). The findings present study is more of less close to biomass values reported by many workers. Jhariya et al. (2014) have estimated

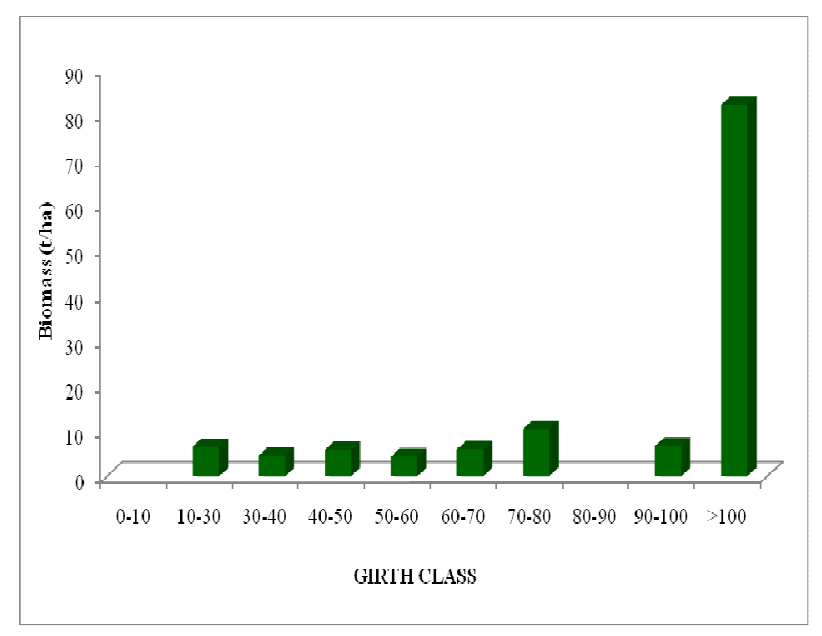

(Fig. 2)

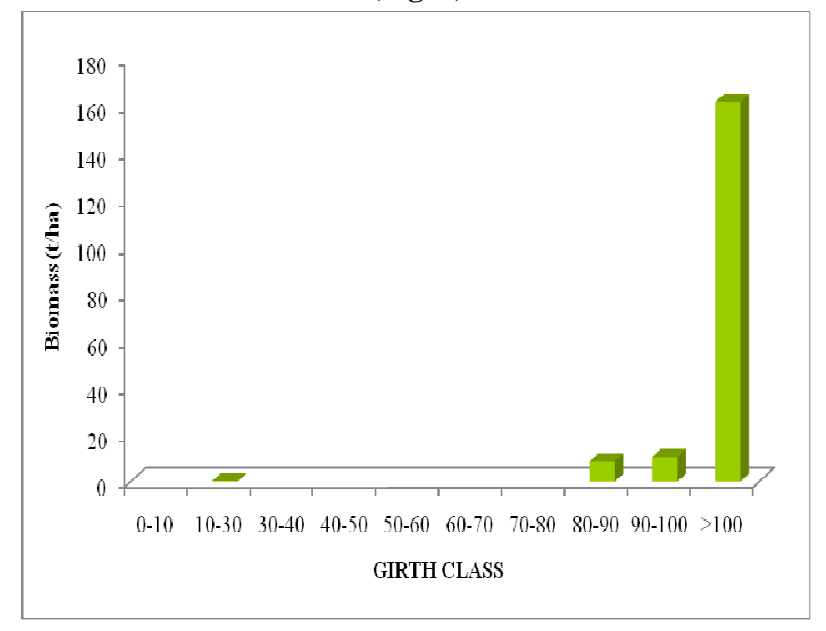

(Fig. 4)

Figs. (1) Distribution pattern of biomass along the girth classes on three different sites (2) Distribution pattern of biomass along the girth classes in least disturbed site (3) in moderately disturbed site (4) in highly disturbed site. 
the total biomass of the Bhoramdeo wildlife sanctuary of Chhattisgarh ranging from 101.43-192.36 $\mathrm{t} \mathrm{ha}^{-1}$ which resemble with the present study (127.69-227.71 $\left.\mathrm{t} \mathrm{ha}^{-1}\right)$. Cairns et al. (2003) have reported that the total above ground biomass of Mexico tropical forest was $225 \mathrm{Mg} \mathrm{ha}^{-1}$ which are closer to present estimates (111.2-199.42 $\left.\mathrm{t} \mathrm{ha}{ }^{-1}\right)$. The present findings are supported by global pattern of above ground biomass $\left(30-273 \mathrm{t} \mathrm{ha}^{-1}\right)$ and total biomass (78-320 $\left.\mathrm{t} \mathrm{ha}^{-1}\right)$ reported by Murphy and Lugo (1986) for the various type of dry tropical forest. Delaney et al. (1997) reported $285 \mathrm{Mg} \mathrm{ha}^{-1}$ above ground biomass of Venezuela Tropical moist forest. The above ground biomass is very similar to Cairns et al. (2000) for the semi-evergreen forest of Yucatan Peninsula (111.2 Mg $\mathrm{ha}^{-1}$ ), but less than the Veracruz (225.8 $\mathrm{Mg} \mathrm{ha}^{-1}$ ). Brown et al. (1995) and Golley et al. (1975) estimated biomass of tropical moist forest and it was found that in the present study biomass was $34 \%$ less than biomass estimates for Brazil tropical moist forest (306 $\mathrm{Mg} \mathrm{ha}{ }^{-1}$ ) and $57 \%$ less than biomass of Panama tropical moist forest $\left(358 \mathrm{Mg} \mathrm{ha}^{-1}\right)$, respectively. Total below ground biomass of present study was between $16.49 \mathrm{t} \mathrm{ha}^{-1}$ and $28.29 \mathrm{t} \mathrm{ha}^{-1}$, which resembled with below ground biomass of tropical deciduous forest estimated by Singh et al. (2009). Hall and Uhling (1991) estimated the biomass of South and South East Asia's forest using the volume estimates and biomass expansion factors derived from Brown et al. (1989). Their biomass estimates for India ranged from $116 \mathrm{Mg}$ $\mathrm{ha}^{-1}$ for undisturbed forest for 60-80 years and 35, 66 and $84 \mathrm{Mg} \mathrm{ha}^{-1}$ for logged, unproductive and managed forests, respectively. Present finding are supported by Borah et al. (2013) where they have reported aboveground tree biomasses in tropical forest of Assam from 32.47 to $261.64 \mathrm{Mg} \mathrm{ha}^{-1}$. Similarly, Thokchom and Yadava (2013) noted the aboveground biomass was in the range of 179.14 to $246.38 \mathrm{Mg} \mathrm{ha}^{-1}$ for sub tropical forests of Manipur, North-East India. Gairola et al. (2011) reported the wide range of aboveground biomass from 172 to $380 \mathrm{Mg} \mathrm{ha}^{-1}$ along an altitudinal gradient in the temperate valley forests of Garhwal. Mohanraj et al. (2011) estimated the $372 \mathrm{Mg}$ $\mathrm{ha}^{-1}$ aboveground biomass of tropical forests of India which was found higher than present estimates. Pande and Patra (2010) estimated the biomass of sal forest and miscellaneous forest of Satpura (Madhya Pradesh) India. The ranges for aboveground biomass $\left(\mathrm{t} \mathrm{ha}{ }^{-1}\right)$ were 154.9-345. They also reported that disturbances in open forests reduce the stand biomass, which resembled with present findings. Yadava (2010) reported the aboveground biomass of sub-tropical broad leaved forest of Manipur between 130 and 255 $\mathrm{Mg} \mathrm{ha}{ }^{-1}$. The present estimates are comparable with the findings of Upadhyay et al. (2009), who studied the effect of disturbance on standing biomass in a sal mixed forest of eastern Uttar Pradesh.

Carbon is the key component of plant and they utilize and store it in different components viz., bole, branch, foliage and roots (Kiran and Shah, 2011). In an ecosystem carbon flows and sinks in the form of biomass by photosynthesis and the electron transport chain in plant system (Atkin et al., 2012). The carbon sequesters potential of forests depends on the type of forest, their age and size class of trees (Terakunpisut $e t$ al., 2007). The most of biomass accumulation in the higher girth class under natural forest ecosystem reveal the key function of large trees in carbon storage. The tropics are much affected by the different biotic interference, the size class distribution of trees an important determination of carbon stock (Baisya et al., 2009). The amount of carbon stored in the tropical forest of the present study (55.125-98.548 $\left.\mathrm{tC} \mathrm{ha}^{-1}\right)$ was similar to the disturbed tropical forests of Sri Lanka (77 $\mathrm{MgC} \mathrm{ha}{ }^{-1}$ ), but lower than the relatively undisturbed matured tropical rain forest of Malaysia (223 Mg C ha-1) reported by Brown and Lugo (1982). Ogawa et al. (1965) reported a carbon stock of 60-179 $\mathrm{tC} \mathrm{ha}{ }^{-1}$ in variety of tropical forest in Thailand. Jhariya et al. (2014) have estimated the total carbon value of tropical forest in Chhattisgarh was varied from 50.71 to $96.18 \mathrm{t} \mathrm{C} \mathrm{ha}^{-1}$ which are similar to present estimated value. The present carbon storage values are comparable with Hall and Uhling (1991), Cairns et al. (2003), Sierra et al. (2007) and Chaturvedi et al. (2011). Metzker et al. (2011) reported 48-91 Mg C ha-1 for tropical forest of Brazil which is line agreement with our findings. Thokchom and Yadava (2013) reported the aboveground carbon stock varied from 81.17 to $118.29 \mathrm{Mg} \mathrm{C} \mathrm{ha}^{-1}$ across the forest study sites. Borah et al. (2013) reported that the aboveground carbon stock in tree species ranged from 16.24 to $130.82 \mathrm{Mg} \mathrm{C} \mathrm{ha}^{-1}$ which is well within the range of present forest $\mathrm{C}$ stock. The present findings are lower than the value documented by Baisya et al. (2009) and Mohanraj et al. (2011). Tang et al. (2012) reported 155 $\mathrm{Mg} \mathrm{C} \mathrm{ha}{ }^{-1}$ for the tropical forest of SW China, while Hoover et al. (2012) 116-125 $\mathrm{MgC} \mathrm{ha}^{-1}$ in above ground compartment.

\section{Conclusion}

The present study reveals that anthropogenic disturbance has a significant impact on regeneration of species, composition, diversity, biomass and carbon storage potential of these tropics. The rise in the anthropogenic disturbances is degrading the forest wealth and quality of the stand. Therefore, there is need of improvement in proper density, stock, species composition and their distribution which can be sink more carbon in their organic biomass. The practice should be opted which disturbs the forest at low scale, maintains the forest composition and structure that are more sustainable for long run.

\section{ACKNOWLEDGEMENT}

Thanks to Forest Department of Chhattisgarh, India for 
necessary support during the field work.

\section{REFERENCES}

Alves, L.F., Vieira, S.A., Scaranello, M.A., Camargo, P.B., Santos, F.A.M., Joly, C.A. and Martinelli, L.A. (2010). Forest structure and live aboveground biomass variation along an elevational gradient of tropical Atlantic moist forest (Brazil). Forest Ecology and Management, 260: 679-691.

Anderson, F. (1970). Ecological studies in a Scandinavian wood land and meadow area. Southern Sweden II. Plant biomass, primary production and turnover of organic matters. Botaniska Notiser, 123: 8-15.

Atkin, B., Gong, T., Harmon, J. and Theodore, M.G. (2012). Carbon Sequestration method. United States Patent, 8,092,118. Assignee: Earth Renaissance Technologies, LLC (Salt Lake City, UT). Current U.S. Class: 405/129. 1; 47/58. ISC. Application No. 12/462,260.

Baisya, R., Barik, S.K. and Upadhayay, K. (2009). Distribution pattern of above ground biomass in natural and plantation forests of humid tropics in NE-India. Tropical Ecology, 50(2): 295-304.

Borah, N., Nath, A.J. and Das, A.K. (2013). Aboveground biomass and carbon stocks of tree species in tropical forests of Cachar districts, Assam, Northeast India. International Journal of Ecology and Environment Sciences, 39(2): 97-106.

Brown, I.F., Martinelli, L.A., Thomas, W.W., Moreira, M.Z., Ferreira, C.A.C. and Victoria, R.A. (1995). Uncertainty in the biomass of Amazonian forests: an example from RondoAnia, Brazil. Forest Ecology and Management, 75: 175-189.

Brown, S. and Lugo, A.E. (1982). The storage and production of organic matter in tropical forests and their role in the global carbon cycle. Biotropica, 14: 161-187.

Brown, S., Gillespie, A.J.R. and Lugo, A.E. (1989). Biomass estimation methods for tropical forests with application to forest inventory data. Forest Science, 35: 881-902.

Brown, S. L., Schroeder, P. and Kern, J. S. (1999). Spatial distribution of biomass in forests of the eastern USA. Forest Ecology and Management, 123: 81-90.

Cairns, M. A., Haggerty, P. K., Alvarez, R., De Jong, B. H. J. and Olmsted, I. (2000). Tropical Mexico's recent land use and change: a region's contribution to the global carbon cycle. Ecological Applications, 10: 1426-1441.

Cairns, M. A., Olmsted, I., Granados, J. and Argaez, J. (2003). Composition and aboveground tree biomass of a dry semi-evergreen forest on Mexico's Yucatan peninsula. Forest Ecology and Management, 186: 125132.

Canadell, J. G., LeQuere, C., Raupanch, M. R., Field, C. B., Buitenhuis, E. T., Ciais, P., Conway, T. J., Gillett, N. P., Houghton, R. A. and Marland, G. (2007). Contribution to accerealating atmospheric $\mathrm{CO}_{2}$ growth from economic activity, carbon intensity and efficiency of natural sink. Proceeding of the National Academy of Science (USA), 104: 18866-18870.

Chaturvedi, R. K., Raghubanshi, A. S. and Singh, J. S. (2011). Carbon density and accumulation in woody species of tropical dry forest in India. Forest Ecology and Management, 262: 1576-1588.

Delaney, M., Brown, S., Lugo, A. E., Torres-Lezama, A. and Quintero, N. B. (1997). The distribution of organic carbon in major components of forests located in life zones of Venezuela. Journal of Tropical Ecology, 13: 697-708.

FSI (2011). India State of Forest Report. Forest Survey of India (MoEF, GOI), Dehradun.

Gairola, S., Sharma, C. M., Ghildiyal, S. K. and Suyal, S. (2011). Live tree biomass and carbon variation along an altitudinal gradient in moist temperate valley slopes of the Garhwal Himalaya (India). Current Science, 100 (10): 1-9.

Golley, F. B., Mcginnis, J. T., Clements, R. G., Child, G. I. and Duever, M. J. (1975). Mineral Cycling in a tropical moist forest ecosystem. University of Georgia Press, Athens, GA.

Hall, C. A. S. and Uhling, J. (1991). Refining estimates of carbon released from Tropical land use change. Canadian Journal of Forest Research, 21: 118-131.

Hoover, C. M., Leak, W. B. and Keel, B. G. (2012). Benchmark carbon stocks from old growth forests in Northern New England, USA. Forest Ecology and Management, 266: 108-114.

Jhariya, M. K. (2014). Effect of forest fire on microbial biomass, storage and sequestration of carbon in a tropical deciduous forest of Chhattisgarh. Ph.D. Thesis, I.G.K.V., Raipur (C.G.), pp. 259.

Jhariya, M. K., Bargali, S. S., Swamy, S. L., Kittur, B., Bargali, K. and Pawar, G. V. (2014). Impact of forest fire on biomass and carbon storage pattern of tropical deciduous forests in Bhoramdeo wildlife sanctuary, Chhattisgarh. International Journal of Ecology and Environmental Sciences, 40(1): 57-74.

Jhariya, M. K., Bargali, S. S., Swamy, S. L. and Kittur, B. (2012). Vegetational structure, diversity and fuel load in fire affected areas of tropical dry deciduous forests in Chhattisgarh. Vegetos, 25(1): 210-224.

Jhariya, M. K. (2010). Analysis of vegetational structure, diversity and fuel load in fire affected areas of tropical dry deciduous forests in Chhattisgarh. M.Sc. Thesis, I.G.K.V., Raipur (C.G.), pp. 86.

Keller, M., Palace, M. and Hurtt, M. (2001). Biomass estimation in the Tapajos national forest, Brazil examination of sampling and allometric uncertainties. Forest Ecology and Management, 154: 371-382.

Ketterings, Q. M., Coe, R., Van Noordwijk, M., Ambagau, Y. and Palm, C. A. (2001). Reducing uncertainty in the use of allometric biomass equations for predicting above ground tree biomass in mixed secondary forests. Forest Ecology and Management, 146: 199-209.

Kiran, S. G. and Shah, K. (2011). Carbon sequestration by urban trees on roadsides of Vadodara city. International Journal of Engineering Science and Technology, 3(4): 3066-3070.

Kittur, B. H., Swamy, S. L., Bargali, S. S. and Jhariya, M. K. (2014). Wildland Fires and Moist Deciduous Forests of Chhattisgarh, India: Divergent Component Assessment. Journal of Forestry Research, (DOI) 10.1007/s11676-014-0471-0.

Metzker, T., Sposito, T. C., Martins, M. T. F., Horta, M. B. and Garcig, Q. S. (2011). Forest dynamics and carbon stocks in Rio Doce state park an Atlantic rainforest hotspot. Current Science, 100(12): 1855-1862.

Mohanraj, R., Saravanan, J. and Dhanakumar, S. (2011). Carbon stock in Kolli forests, Eastern Ghat (India) with emphasis on aboveground biomass, litter, woody debris and soil. Forest Biogeosciences and Forestry, 4: 
61-65.

Murphy, P. G. and Lugo, A. E. (1986). Ecology of tropical dry forest. Annual Review of Ecology and Systematics, 17: $67-88$.

Ogawa, H., Yoda, K., Ogino, K. and Kira, T. (1965). Comparative ecological studies on three main types of forest vegetation in Thailand. II. Plant biomass. Nature Life S.E. Asia, 4: 49-80.

Ovington, J. D. (1962). Quantitative ecology and woodland ecosystem concept. Advance Ecological Research, 1: 103-183.

Pande, P. K. and Patra, A. K. (2010). Biomass and productivity in $\mathrm{Sal}$ and miscellaneous forests of Satpura plateau (Madhya Pradesh) India. Advances in Bioscience and Biotechnology, 1: 30-38.

Pawar, G. V., Singh, L., Jhariya, M. K. and Sahu, K. P. (2012). Regeneration status in relation to anthropogenic disturbance in tropical deciduous forest of Chhattisgarh. The Ecoscan, (Special Issue) 1: 281-285.

Sahu, K. P., Singh, L., Alone, R. A., Jhariya, M. K. and Pawar, G. V. (2013). Biomass and carbon storage pattern in an age series of teak plantation in dry tropics. Vegetos, 26(1): 205-217.

Sierra, C. A., Del Valle, J. I., Orrego, S. A., Moreno, F. H., Harmon, M. E., Zapata, M., Calorado, G. J., Herrera, M. A., Lata, W., Restrepo, D. E., Berrouet, L. M., Loaiza, L. M. and Benjumea, J. F. (2007). Total carbon stocks in a tropical forest landscape of Porce region, Colombia. Forest Ecology and Management, 243: 299-309.

Singh, K. P. and Misra, R. (1979). Structure and Functioning of Natural Modified and Silvicultural Ecosystems in Eastern Uttar Pradesh, 160 pp. Final Technical Report (1975-1978), MAB, Research Project, Banaras Hindu University.

Singh, L. and Singh, J. S. (1991). Species structure, dry matter dynamics and carbon flux of a dry tropical forest in India. Annals of Botany, 68: 263-273.

Singh, L., Yadav, D. K., Pagare, P., Lekha, G. and Thakur, B. S. (2009). Impact of land use changes on species structure, biomass and carbon storage in tropical deciduous forest and converted forest. International Journal of Ecology and Environmental Sciences, 35 (1): 113-119.

Tang, J. W., Yin, J. X., Qi, J. F., Jepsen, M. R. and Lu, X. T. (2012). Ecosystem carbon storage of tropical forests over limestone in Xishuangbanna, SW China. Journal of Tropical Forest Sciences, 24(3): 399-407.

Terakunpisut, J., Gajaseni, N. and Ruankawe, N. (2007). Carbon sequestration potential in aboveground biomass of Thong pha phun national forest, Thailand. Applied Ecology and Environmental Research, 5: 93102.

Thokchom, A. and Yadava, P. S. (2013). Biomass and carbon stock assessment in the sub-tropical forests of Manipur, North-East India. International Journal of Ecology and Environment Science, 39(2): 107-113.

Upadhyay, R., Singh, J. and Singh, B. (2009). Effect of disturbance on standing biomass in a sal mixed forest of eastern U.P. Indian Journal of Forestry, 32(2): 251256.

Usuga, J. C. L., Toro, J. A. R., Alzate, M. V. R. and Tapias, A. J. L. (2010). Estimation of biomass and carbon stocks in plants, soil and forest floor in different tropical forests. Forest Ecology and Management, 260: 1906-1913.

Yadava, P. S. (2010). Soil and vegetation carbon pool and sequestration in the forest ecosystem of Manipur, NE India. Pages 163-170, In: Qasim, S.Z. and Goel, M. (Editors) $\mathrm{CO}_{2}$ Sequestration Technology for Clean Energy. Daya Publication House, New Delhi. 